\title{
THE EFFECT OF SLEEVE GASTRECTOMY ON METABOLIC DISORDERS
}

\author{
By

\section{Ahmed Shawky Abd El-Aziz, Mohammed Hassan El-Shafey and Emad El-Sebaey Oan}

Departments of General Surgery, Al -Azhar University, Cairo, Egypt

Corresponding author: Emad El-Sebaey Oan,

Mobile: 01225566471, E-mail: EmadOan78@ gmail.com

\begin{abstract}
Background: Obesity has become a major health problem in both developed and developing countries in twenty first century because of its high prevalence and its relationship with serious medical and psychological complications.
\end{abstract}

Objective: To evaluate the short term effect of sleeve gastrectomy on metabolic disorders.

Patients and Methods: Fifty morbid obese patients (30 male and 20 female) aged between 21 to 56 years with BMI range between $(41-70) \mathrm{kg} / \mathrm{m} 2$ were enrolled in this study. Patients were followed up after 3 and 9 months after operation (LSG) to monitor their BMI, blood pressure, fasting blood glucose, serum cholesterol level, triglycerides, LDL and HDL cholesterol level).

Results: our study shows that LSG has a significant effect on hypertension and type 2 DM inducing resolution or improvement in the majority of cases. Nine month after operation there is a significant decrease in lipid profile (Total Cholesterol, Triglyceride and LDL cholesterol).

Conclusion: LSG very good bariatric procedure with the simplicity of the technique and less complications with good results on both body weight reduction and BMI.

Keywords: Sleeve gastrectomy, metabolic disorders.

\section{INTRODUCTION}

Obesity has become a major health problem in both developed and developing countries in twenty first century because of its high prevalence and its relationship with serious medical and psychological complications (Singh et al., 2011).

Clinical assessment is important in the management of the morbidly obese patients. The assessment includes the body mass index, waist circumference, comorbid risk factors and psychological evaluation (Jacobs et al., 2010).
Bariatric surgery is recommended for patients with a BMI index $\geq 40 \mathrm{~kg} / \mathrm{m} 2$ or a BMI $\geq 35 \mathrm{~kg} / \mathrm{m}^{2}$ with comorbidities (Leong and Taheri, 2012).

Laparoscopic sleeve gastrectomy (LSG) is one of the most common restrictive bariatric surgeries. It includes resection of a large part of the body and the fundus of the stomach along the greater curvature to provide decreased appetite and increased satiety (Todkar et al., 2010). 
This study aimed to evaluate the short term effect of sleeve gastrectomy on metabolic disorders.

\section{PATIENTS AND METHODS}

A prospective study done on fifty morbid obese patients (30 male and 20 female) aged between $21-56$ years with BMI range between $41-70 \mathrm{~kg} / \mathrm{m}^{2}$.

Laparoscopic sleeve gastrectomy was performed for all patients at general surgery department at Al-Hussein Hospital, Al - Azhar University in Cairo, Egypt, during the time between March 2018 and January 2020.

An approval from ethical committee at the Faculty of Medicine, Al-Azhar University was obtained.

The procedures and the aim of the study were clearly explained to the patient and family. A written consent was obtained from the patient before enrollment into the study.

Patients included in our study were complaining from morbid obesity with one or more metabolic disorders (type 2 DM, hypertension and dyslipidemia).
Patients who had a history of psychiatric disorders, drug and alcohol addiction, hiatal hernia, advanced malignancy, recent cardiac attack and sever diseases with major risk of surgical and anaesthetic complication were excluded from our study.

All patients planned for surgery was followed up preoperatively and 3 months and 9 months after surgery by measurement of the following: BMI, systolic and diastolic blood pressure, fasting blood glucose and lipid profile (Total cholesterol, Triglyceride, HDL and LDL).

The data were introduced to a personal computer using Statistical Package for Social Science (SPSS), tabulated and statistically processed. Data were expressed as Mean \pm SD for quantitative parametric measures and both number and percentage for categorized data. Analytical statistics was done using one way ANOVA test followed by Post-hoc tests (Tukey's test and Scheffe's Method).

\section{RESULTS}

Fifty adult patients comprising 30 males and 20 females, aged between 21 and 56 years suffering from morbid obesity with one or more metabolic disorders were enrolled in this study.
The average age of the patients included in our study was $42.8 \pm 8.2 \mathrm{Ys}$ (Table 1). 
Table(1): Demogarphic criteria of obese patients

\begin{tabular}{|c|c|c|c|}
\hline \multirow{2}{*}{ Parameters } & Count & $\mathbf{N}$ & $\%$ \\
\hline \multirow{2}{*}{ Sex } & Male & 30 & 60.00 \\
\cline { 2 - 4 } & Female & 20 & 40.00 \\
\hline \multirow{2}{*}{ Age (Years) } & Range & \multicolumn{2}{|c|}{$21-56$} \\
\cline { 2 - 3 } & Mean \pm SD & $42.840 \pm 8.220$ \\
\hline \multirow{2}{*}{ Height (cm) } & Range & $150-190$ \\
\cline { 2 - 3 } & Mean \pm SD & $168.280 \pm 8.164$ \\
\hline
\end{tabular}

The averge BMI of the patients was $(52.4 \pm 6.6) \mathrm{kg} / \mathrm{m}^{2}$. The mean BMI of our patients $3 \mathrm{Ms}$ and $9 \mathrm{Ms}$ after surgery decreased by $(8.4$ and 19$) \mathrm{kg} / \mathrm{m}^{2}$ respectively (Table2).

Table (2): Description of BMI at preoperative , 3 months and 9 months after surgery

\begin{tabular}{|c|c|c|c|c|c|c|c|c|c|}
\hline \multirow{2}{*}{ Time } & \multicolumn{7}{|c|}{ Rarameters } & \multicolumn{5}{|c|}{ BMI } & Mean & \pm & SD & COMP & Mean \pm SD & P-Value \\
\cline { 2 - 9 } & 41 & - & 70.2 & 52.460 & \pm & 6.634 & Preop-post3M & $8.484 \pm 1.959$ & $<0.001$ \\
\hline $\begin{array}{c}\text { Pre-operative } \\
\begin{array}{c}\text { Post-operative 3 } \\
\text { Months }\end{array}\end{array}$ & 36 & - & 62.2 & 43.976 & \pm & 5.449 & preop-post9M & $19.032 \pm 3.576$ & $<0.001$ \\
\hline $\begin{array}{c}\text { Post-operative 9 } \\
\text { Months }\end{array}$ & 24.9 & - & 48.8 & 33.428 & \pm & 4.353 & Post3M-Post9M & $10.548 \pm 2.268$ & $<0.001$ \\
\hline
\end{tabular}

The mean systolic blood pressure of our patients 3 months and 9 months after surgery decreased by 8.6 and $15.6 \mathrm{mmHg}$ respectively. The mean diastolic blood pressure of our patients 3 months and 9 months after surgery decreased by 5.4 and $11 \mathrm{mmHg}$ respectively (Table 3 ).

Table (3): Description of Systolic and diastolic blood pressure at preoperative, 3 months and 9 months after surgery

\begin{tabular}{|c|c|c|c|c|c|c|}
\hline Pariables & Time & Range & $\begin{array}{c}\text { Mean } \pm \\
\text { SD }\end{array}$ & СОМP & $\begin{array}{c}\text { Mean } \pm \\
\text { SD }\end{array}$ & $\begin{array}{c}\text { P- } \\
\text { value }\end{array}$ \\
\hline \multirow{3}{*}{$\begin{array}{c}\text { SBP } \\
(\mathrm{mmHg})\end{array}$} & Pre-operative & $130-180$ & $\begin{array}{l}148.8 \pm \\
13.422\end{array}$ & Preop-Post3M & $\begin{array}{c}8.600 \pm \\
8.633\end{array}$ & $<0.001$ \\
\hline & $\begin{array}{c}\text { Post-operative } 3 \\
\text { Months }\end{array}$ & $120-160$ & $\begin{array}{c}140.2 \pm \\
10.15\end{array}$ & Preop-Post9M & $\begin{array}{c}15.600 \pm \\
10.625\end{array}$ & $<0.001$ \\
\hline & $\begin{array}{c}\text { Post-operative } 9 \\
\text { Months }\end{array}$ & $120-150$ & $\begin{array}{c}133.2 \pm \\
7.407\end{array}$ & Post3M-Post9M & $\begin{array}{l}7.000 \pm \\
5.345\end{array}$ & $<0.001$ \\
\hline \multirow{3}{*}{$\begin{array}{c}\text { DBP } \\
(\mathrm{mmHg})\end{array}$} & Pre-operative & $80-110$ & $\begin{array}{c}96.6 \\
\pm 8.657\end{array}$ & Preop-Post3M & $\begin{array}{c}5.400 \pm \\
4.932\end{array}$ & $<0.001$ \\
\hline & $\begin{array}{c}\text { Post-operative } 3 \\
\text { Months }\end{array}$ & $80-100$ & $\begin{array}{c}91.20 \pm \\
6.590\end{array}$ & Preop-Post9M & $\begin{array}{l}11.000 \pm \\
5.714\end{array}$ & $<0.001$ \\
\hline & $\begin{array}{c}\text { Post-operative } 9 \\
\text { Months }\end{array}$ & $80-90$ & $\begin{array}{c}85.60 \pm \\
5.014\end{array}$ & Post3M-Post9M & $\begin{array}{c}5.600 \pm \\
5.771\end{array}$ & $<0.001$ \\
\hline
\end{tabular}

There was a statistically significant decrease of FBG 3 months and 9 months after surgery (Table 4). 
Table (4): Description of fasting blood glucose level at preoperative, 3 months and 9 months after surgery

\begin{tabular}{|c|c|c|c|c|c|c|c|}
\hline \multirow{2}{*}{ Time } & \multicolumn{5}{|c|}{ FBG (mg/dl) } & \multirow{2}{*}{ COMP } & $\begin{array}{c}\text { Mann-Whitney } \\
\text { Test }\end{array}$ \\
\cline { 2 - 6 } \multicolumn{1}{|c|}{ Pre-operative } & 73 & - & 270 & 105 & $(94-136.25)$ & Pre-P3M & $<0.001$ \\
\hline Post-operative 3 Months & 74 & - & 210 & 100 & $(83-110)$ & Pre-P9M & $<0.001$ \\
\hline Post-operative 9 Months & 71 & - & 150 & 95 & $(83.75-100)$ & P3M-P9M & $<0.001$ \\
\hline
\end{tabular}

The mean total cholesterol level of our patients 3 months and 9 months after surgery decreased by 21.4 and $42.1 \mathrm{mg} / \mathrm{dl}$ respectively. The mean triglyceride level 3 months and 9 months after surgery decreased by 14.5 and $30.8 \mathrm{mg} / \mathrm{dl}$ respectively. The mean LDL level 3

Table (5): Description of lipid profile at preoperative, 3 months and 9 months after surgery

\begin{tabular}{|c|c|c|c|c|c|c|}
\hline \multirow{2}{*}{$\begin{array}{l}\text { Lipid } \\
\text { Profile }\end{array}$} & \multicolumn{2}{|c|}{ Preoperative } & \multicolumn{2}{c|}{ Posoperative 3 months } & \multicolumn{2}{c|}{ Posoperative 9 months } \\
\cline { 2 - 7 } & Range & Mean \pm SD & Range & Mean \pm SD & Range & Mean \pm SD \\
\hline $\begin{array}{c}\text { Cholesterol } \\
\text { (mg/dl) }\end{array}$ & $137-320$ & $234.800 \pm 37.904$ & $130-274$ & $213.40 \pm 31.526$ & $130-240$ & $192.680 \pm 24.735$ \\
\hline TG (mg/dl) & $111-190$ & $146.560 \pm 20.498$ & $100-170$ & $132.040 \pm 19.276$ & $60-155$ & $115.720 \pm 24.576$ \\
\hline LDL (mg/dl) & $65-233$ & $145.120 \pm 33.661$ & $60-200$ & $132.960 \pm 28.723$ & $62-153$ & $118.080 \pm 17.739$ \\
\hline HDL (mg/dl) & $30-58$ & $42.840 \pm 5.633$ & $39-60$ & $46.720 \pm 5.997$ & $40-63$ & $51.120 \pm 6.097$ \\
\hline
\end{tabular}

According to the analysis of obtained material it is possible to count that:

The average age of the patients included in our study was $(42.8 \pm 8.2)$ Ys \{Range from $21-56$ Ys .

The average body weight of the patients was $147.8 \pm 14 \mathrm{~kg}$ \{ Range from $117-174 \mathrm{~kg}$.

The mean body weight of our patients 3 months and 9 months after surgery decreased by 23.8 and $53.6 \mathrm{~kg}$ respectively.

The averge BMI of the patients was $52.4 \pm 6.6 \mathrm{~kg} / \mathrm{m}^{2}$. \{Range from $41-70$ $\left.\mathrm{kg} / \mathrm{m}^{2}\right\}$.

The mean BMI of our patients 3 months and 9 months after surgery decreased by 8.4 and $19 \mathrm{~kg} / \mathrm{m}^{2}$ respectively.

The mean systolic blood pressure of our patients 3 months and 9 months after months and 9 months after surgery decreased by 12.1 and $27 \mathrm{mg} / \mathrm{dl}$ respectively. The mean HDL level 3 months and 9 months after surgery increased by 3.8 and $8.2 \mathrm{mg} / \mathrm{dl}$ respectively (Table 5). surgery decreased by 8.6 and $15.6 \mathrm{mmHg}$ respectively.

The mean diastolic blood pressure of our patients 3 months and 9 months after surgery decreased by 5.4 and $11 \mathrm{mmHg}$ respectively.

The mean total cholesterol level of our patients 3 months and 9 months after surgery decreased by 21.4 and $42.1 \mathrm{mg} / \mathrm{dl}$ respectively.

The mean triglyceride level of our patients 3 months and 9 months after surgery decreased by 14.5 and $30.8 \mathrm{mg} / \mathrm{dl}$ respectively.

The mean HDL level of our patients 3 months and 9 months after surgery increased by 3.8 and $8.2 \mathrm{mg} / \mathrm{dl}$ respectively.

The mean LDL level of our patients 3 months and 9 months after surgery decreased by 12.1 and $27 \mathrm{mg} / \mathrm{dl}$ respectively. 


\section{DISCUSSION}

The main purpose of this study was to evaluate the short term effect of LSG on metabolic disorders.

In this study the mean BMI of patients $3 \mathrm{Ms}$ and $9 \mathrm{Ms}$ after surgery decreased by 8.4 and $19 \mathrm{~kg} / \mathrm{m}^{2}$ respectively.

Another study performed by Hutter et al. (2011) showed that the average reduction in the mean $\mathrm{BMI}$ for patients undergoing LSG was $8.75 \mathrm{~kg} / \mathrm{m}^{2}$ at 6 months and $11.87 \mathrm{~kg} / \mathrm{m}^{2}$ at 1 year post operation.

Nine months after surgery we found that $63 \%$ of our patients who were on oral hypoglycemic drugs required decrease drug dose while $37 \%$ of them stopped the treatment.

In another study prepared by Gill et al. (2010), they stated that $66.2 \%$ of patients who underwent sleeve gastrectomy were completely cured from type 2 diabetes which was reflected by an overall improvement in fasting glucose levels allowing the termination of all diabetic medications.

In another study performed at Cleveland clinic by Schauer et al. (2012) in which they compared sleeve gastrectomy (SG) to medical management on type 2 diabetic patients, they found that not only there was a significant reduction in the use of oral hypoglycemic drugs but also after 1 year of follow-up only $8 \%$ of $\mathrm{SG}$ patients required insulin.

Our results showed that there is a significant decrease in the percentage of patients with high blood pressure at 9 months after surgery.
There have been many recent studies that have shown improvement or resolution of hypertension following LSG. A multi-center study by Sanchez et al. (2009) found that hypertension was improved in $63 \%$ of LSG patients.

In another cohort study, Basso et al. (2011) found that out of 100 high-risk super obese patients with a mean BMI of $54.4 \mathrm{~kg} / \mathrm{m}^{2}$ had complete resolution of their hypertension in $62 \%$ of cases.

Our study showed a significant decrease in lipid profile (Total Cholesterol, Triglyceride and LDL cholesterol) nine months after LSG.

Similar results were obtained by Vidal et al. (2008) with a significant improvement of lipid profile following LSG.

Another study performed by Zhang et al. (2011) showed that high-density lipoprotein cholesterol (HDL) and triglycerides were significantly improved after LSG but low-density lipoprotein cholesterol (LDL) and total cholesterol were not improved.

\section{CONCLUSION}

LSG is a very good bariatric procedure with the simplicity of the technique and less complications with good results on both body weight reduction and BMI.

LSG played an important role in the correction of metabolic disturbance associated with obesity especially DM type 2, hypertension and dyslipidemia early after the operation.

The short term follow up period after operation with low number of patients 
included in the study were potential limitations of our study.

\section{REFERENCES}

1. Basso N, Capoccia D and Rizzello $M$ (2011): First-phase insulin secretion, insulin sensitivity, ghrelin, GLP-1, and PYY changes $72 \mathrm{~h}$ after sleeve gastrectomy in obese diabetic patients: the gastric hypothesis. Surg Endosc., 25: 3540-3550.

2. Gill RS, Birch DW, Shi X, Sharma AM and Karmali $S$ (2010): Sleeve gastrectomy and type 2 diabetes mellitus: a systematic review. Surg Obes Relat Dis., 6: 1-10.

3. Hutter MM, Schirmer BD, Jones DB, Ko CY, Cohen ME, Merkow RP and Nguyen NT (2011): First report from the American College of Surgeons Bariatric Surgery Center Network: laparoscopic sleeve gastrectomy has morbid-ity and effectiveness positioned between the band and the bypass. Ann Surg., 254 (3): 410420; discussion 420- 412 .

4. Jacobs EJ, Newton $\mathrm{CC}$ and Wang $\mathrm{Y}$ (2010): Waist circumference and all-cause mortality in a large US cohort. Arch Intern Med., 170: 1293.

5. Leong WB and Taheri $S$ (2012): The role of bariatric surgery in the treatment of type 2 diabetes mellitus. J R Coll Physicians Edinb., 42: 194- 8 .

6. Sanchez-Santos R, Masdevall C, Baltasar A, Martinez- Blazquez C, Garcia Ruiz de Gordejuela A, Ponsi $E$ and SanchezPernaute A (2009): Short- and mid-term out- comes of sleeve gastrectomy for morbid obesity: the experience of the Spanish National Registry. Obes Surg., 19 (9): 12031210.

7. Schauer PR, Kashyap SR, Wolski K Brethauer SA, Kirwan JP and Pothier CE (2012): Bariatric surgery versus intensive medical therapy in obese patients with diabetes. N Engl J Med., 366: 1567- 1576.

8. Singh RB, Pella $D$ and Mechirova $V$ (2011): Prevalence of obesity physical inactivity and under nutrition, a triple burden of diseases during transition in a developing economy. The Five City Study Group. Acta Cardiol., 62: 119.

9. Todkar JS, Shah SS, Shah PS and Gangwani J (2010): Long-term effects of laparoscopic sleeve gastrectomy in morbidly obese subjects with type 2 diabetes mellitus. Surg Obes Relat Dis., 6 (2):142- 5.

10. Vidal J, Ibarzabal A, Romero F, Delgado S and Momblan D (2008): Type 2 diabetes mellitus and the metabolic syndrome following sleeve gastrectomy in severely obese subjects. Obes Surg., 18: 1077-1082.

11. Zhang F, Strain GW, Lei W, Dakin GF and Gagner $M$ (2011): Changes in lipid profiles in morbidly obese patients after laparoscopic sleeve gastrectomy (LSG). Obes Surg., 21: 305- 309. 


\section{تأثيز عملية تكميم المعدة على إضطر ابات التمثيل الغذائي أحمد شوقي عبد العزيز، محمد حسن الثافعي، عماد السباعي عون}

قسم الجراحة العامة، كلية الطب، جامعة الأزهر (القاهرة)

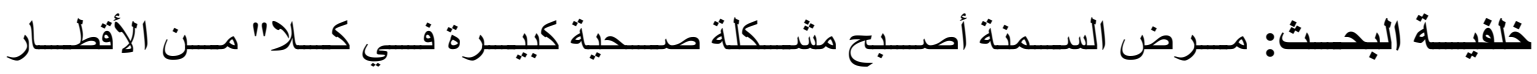

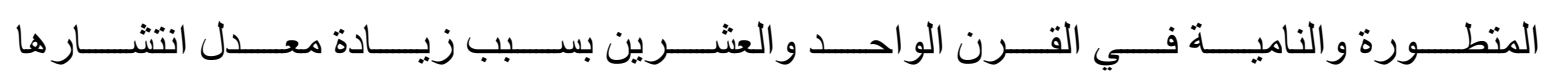
و علاقتها بحدوث مضاعفات طبية ونفسية خطيرة.

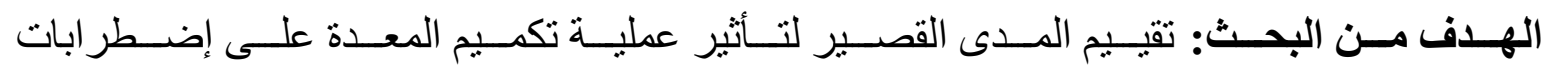
التمثيل الغذائي.

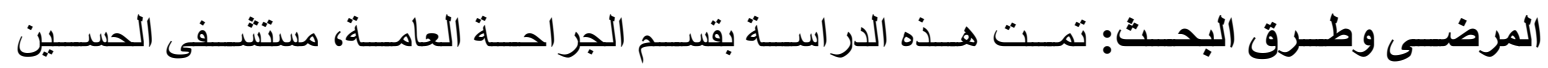

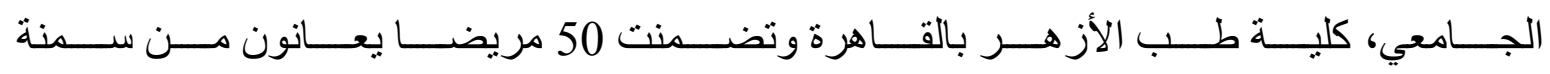

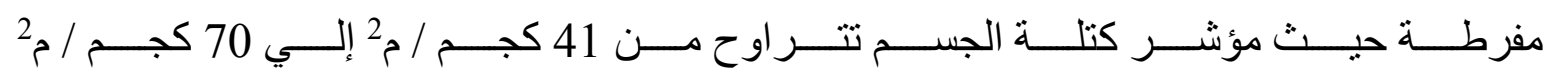

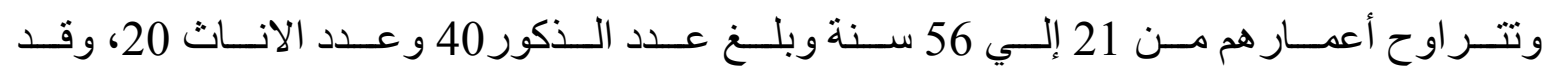

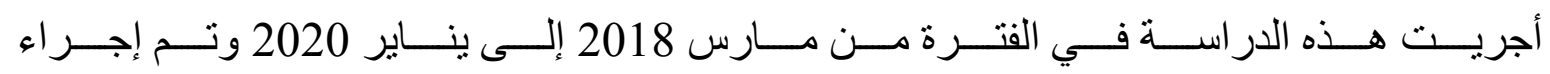

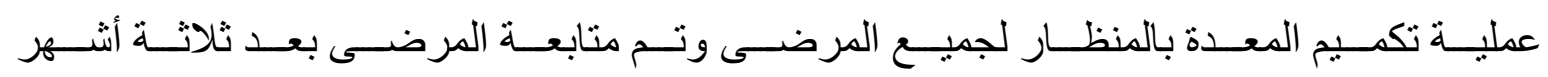

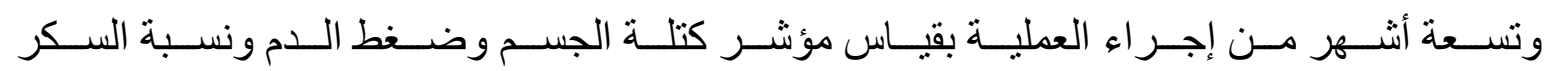

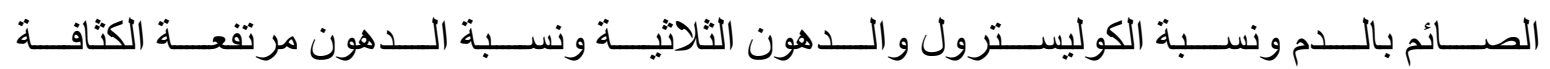
ومنخفضة الكثافة بالام.

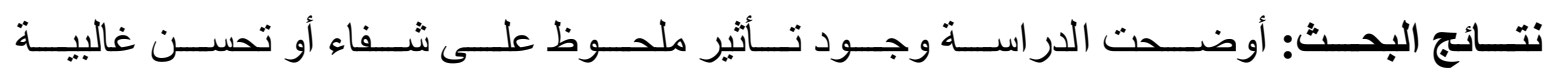

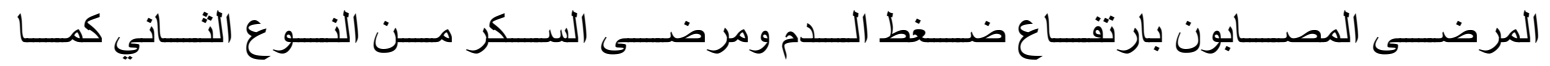

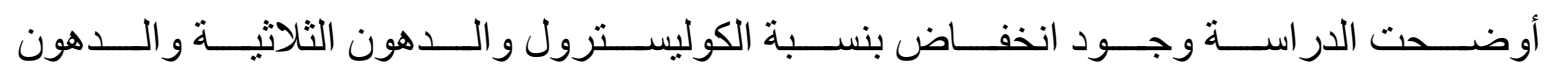
منخفضة الكثافة بالام.

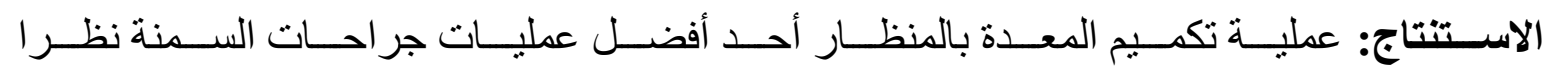

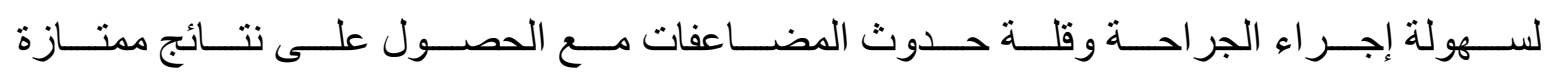

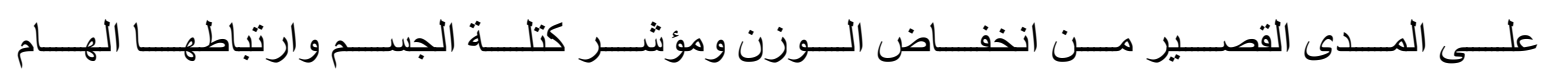
بتحسن نسب الاضطر ابات الأيضية المنصلة بالسمنة. 